\title{
College Student's Stress and Associated Demographic Correlates
}

\author{
Susheelabai Srinivasa ${ }^{1}$ \\ ${ }^{1}$ School of Social Work, University of Texas Rio Grande Valley, United States. \\ Correspondence: Assistant Prof. Susheelabai Srinivasa, School of Social Work, University of Texas Rio Grande Valley, \\ United States.
}

Received: August 17, 2020

Accepted: September 17, $2021 \quad$ Available online: September 27, 2021

doi:10.11114/ijsss.v9i6.5363

URL: https://doi.org/10.11114/ijsss.v9i6.5363

\begin{abstract}
Several research studies consistently identified that college student's experience stress. However, there is hardly any substantive research that compared stress and its demographic correlates among international and American students. The current study, to address the knowledge gap in the literature, gathered data from the participants with multiethnic and cultural backgrounds. It provides perspective and insight into the stressors affecting international and American students and differences between them. The study collected data using a survey instrument from a sample of 221 students (90 international and 131 American students) at a mid-size public university in Midwestern region in the United States. The study findings confirmed the results of prior research studies that international students experienced low levels of stress than the American students. Among the demographic's particulars, gender emerged as a key predictor of stress among both the groups. In addition, age and socioeconomic background too emerged as significant correlates of stress among students in both sample groups. Lower economic status of students caused moderate to severe levels of stress in both American and international groups compared to high income students.
\end{abstract}

Keywords: stress, international students, American college students, demographic variables

\section{Introduction}

Stress and anxiety are common problems in modern lifestyle (Vroegap, 1975). College students encounter various challenges to achieve academic success. Appley and Trumbull (1967) pointed out stress is not an outcome of a single event or factor, but it rather results from a combination of factors and the whole organism in the context of stressful environment. Stress manifests when internal demands, environmental demands, or both exceed the individual's adaptive resources (Lazarus, 1985). Some significant factors that cause stress include heredity, personality, emotions, prior experience and environmental conditions (Cloud, 1991). Belief systems are often unrecognized source of stress (Ellis, 1989). Individuals respond to stressful situations in certain unique ways based on their prior experience and learning in the social environment (Atkinson, 1988). Long term stress and stress accumulation have a potential to damage individual's homeostasis or equilibrium, coping mechanisms, and exhaust their personal resources (Atkinson, 1988; Cannon, 1929). The damages from stress can range from getting upset due to stress, psychosomatic symptoms, and onset of a disease, thus causing irreparable damage to internal systems of the body (Selye, 1956), and pave the way for health problems. When such a degeneration has occurred, it means an individual has failed to adapt an effective coping strategy to overcome stress (Lazarus \& Folkman, 1984). Transitioning into college is a distinct phase in modern life, which is daunting for both American and international students as it has a variety of challenges. Both academic and non-academic challenges may place heavy demand on resources and resilience to succeed. This phenomenon, though researched in the past, is currently under-researched because a complete body of knowledge is not available to engage in preventive efforts to reduce stress among students.

American students experienced higher levels of stress than international students, and those women experienced more stress than men (Misra, Crist, \& Byrant, 2003; Misra \& Castillo, 2004). In an assessment of general life stress among international and American students (Leong, Mallinckrodt, \& Kralj, 1990) found that international students experienced fewer stressful events than their American counterparts. The current study addressed this gap in the literature on stress. The popular perception is that international students might experience more stress due to migration into a new sociocultural environment and being away from their social support system (of their families and friends) which was available in their respective countries. The researcher wanted to find out the level of stress and its demographic correlates for the international and the American students. Using the Gadzella's Student Life Stress Inventory (SLSI, 1991) 
framework to assess stress among college students. This inventory is a highly reliable and valid tool to assess and compare levels of stress among sub-populations.

\subsection{Stress among College Students}

The author argues that stress affects college students' adaptation to life-events and academic performance. Harris (1972) study reported stressful life events impacted college student's adaptation as a significant finding. It was also evident from the prior research that stressful life events in student's life (in their families and outside) heightened students' level of anxiety, depression, and body pains.

Higher levels of stress resulted in anxiety and depression as identified by (Almawi, Tamim, Al-Sayed, et al.; Boyton Health Services, 2009). Obesity, heart disease, cancer, Cushing's syndrome, anorexia nervosa, and chronic fatigue syndrome were associated with negative health outcomes and higher levels of chronic stress (NICHCD, 2009). Further, such conditions resulted in compromised cognitive and social functioning (Clarke, 1995; Newcomb, Huba, \& Bentler, 1981; Sherman \& Walls, 1995; Siegel \& Brown, 1988; Tolan et al., 1988).

The college students' life is associated with a set of role expectations, career demands, financial needs, family needs, and unexpected life events which can all be potential sources of stress (Abouserie, 1994; Gadzella, 1991; Pierceall \& Meim, 2007). Students may experience stress due to failure in meeting their academic goals (Arnett, 2000; Roisman et al., 2004). Specifically, female students reported that they were unable to meet their gender role expectations, which resulted in role-conflict, marital stress, and depression (Aneshensel, 1986; McBride, 1990). Women have made transition in their role from home to work but their role at home remains largely unaltered in the absence of shared responsibility of household chores (Vanfossen, 1981; Yogev, 1981). Another aspect of stress among female students is migration of their spouses in search of better job prospects. Often this results in women following them and making transitions which has potential for accumulated stress and environmental stress. Gender dimension of this aspect is that women's work is considered as secondary, subsidiary to a man's work or less significant (Barret, 1979). When it comes down to the case of international women students, they are bound to have a double disadvantage, firstly, being a woman and secondly, being an international student (Beiner, \& Baruch, 1987). Overall, women have multiple role responsibilities from being wives, mothers, and students make them vulnerable and situate them at greater risk for stress as students (Gilbert \& Holahan, 1982; Gilbert \& Rachlin, 1987; McBride, 1990). Both women and men have the need to stay connected, emotionally and socially, and benefit from social and intimate relationships. Difficulty in meeting their emotional and social needs aggravate their situation and compound their stress (Pearlin et al., 1981). Gaps in college completion was based on the family income as pointed by (Bailey \& Dynarski, 2011; Belley \& Lochner, 2007). Furthermore, evidence revealed that $74 \%$ of students from higher economic status and $41 \%$ of the students from low economic backgrounds graduated (Kena et al., 2015).

\subsection{Stress among International Students}

One of the hypotheses of this study was that international students may experience higher levels of stress compared to American students. Previous research on international students reported they experienced problems due to conflict in cultural values, language barriers, academic load and demands, lack of effective and consistent study habits, lack of time management hurdles in meeting people, maintaining good social relationships, being separated from family, friends and the home environment, as well as challenges in adjusting to the new environment (Lewthwaite, 1996).

International students feel pressured to achieve academic success by securing top grades and ranks (Mori, 2000; Zwingmann \& Gunn, 1983). These pressures may be more compelling for students whose parents and teachers place high expectations on them from their formative years (Lee \& Ying, 2001), and for those who view academic achievement as a culturally expected and accepted means to attain financial security and social status (Sue \& Okazaki, 1990).

Academic and financial concerns were related to symptoms of distress (Ying \& Liese, 1991). Financial aid for students impacted wellbeing among Taiwanese international students. International students faced financial insecurity and in extreme cases had to return to their home countries (Church, 1982).

A common phenomenon experienced by international students arriving in the United States is culture shock, depression, and disappointment (Oberg, 1960). Culture shock was reported as a source of stress for many international students (Leong, Mallinckrodt, \& Kralj, 1990). International students felt excited to come abroad to study but later found the process stressful (Bradley, 2000). They may face difficulties in the acculturation process and adapting to the academic environment and cultural context, as well as from living independently with limited social support (Yoon \& Portman, 2004).

Non-acceptance and fear of shamefulness prevented international students from sharing and hence they refrained sharing such attitudes with the people in the host country. Cultural differences can mask such symptoms and create a 
false impression of well-being. Consequently, all this could have a lasting and adverse effect on individuals' self-confidence and self-esteem which can affect students' academic performance. Wan, Chapman, and Biggs (1992) revealed international students often experience difficulties in adjusting to heavy academic demands, fast-paced faculty-student interaction, and limited social support compared to American graduate students while American students who lived off-campus often felt excluded from the mainstream (Leong, Mallinckrodt, \& Kralj, 1990; Wei, Heppner, Mallen, $\mathrm{Ku}, \mathrm{Liao}, \& \mathrm{Wu}, 2007)$. The American educational environment seemed to have aggravated these problems.

Ying, Lee, and Tsai (2004) found ethnic minority college students faced challenges in the cultural, academic, social, and practical aspects of life, and these aspects were more challenging for less academically advanced students. This research linked problems with academic expression and dependency on Chinese language on the one hand, to racism and cross-cultural communication problems on the other. Students from China with limited English language skills reported higher levels of stress and expressed a desire for counseling services.

Incoming international students from India and China faced problems with housing and frequent ill health but received good peer support. Lewthwaite (1996) reported that increasing number of international students suffered from mental health problems due to difficulty in adapting to new cultural as well as academic environments. Research by (Misra et al., 2003; Misra \& Castillo 2004) found American students experienced higher levels of stress than international students. Finally, American students who lived with family members felt isolated from campus life (Ying, Lee, \&Tsai, 2004).

\subsection{Gender and Stress among College Students}

Gender has been associated with stress and unhealthy habits in college students (Hirsch \& Ellis, 1996) with women appearing to exhibit stress in the form of depressive symptoms (Aneshensel, 1988). Gender differences in response to stress were reported by (Beena \& Poduval,1992; Abouserie,1994; Hudd et al.,2000; Rao, Moudad, \& Subbhakrishna, 2000; Pierceall \& Keim, 2007).

\subsection{The Present Study}

The current research focuses on stress among international students in comparison to American students and associated demographics with regards to international and American students. The international students sample covered in this study includes Indians, Chinese, and other nationalities. Demographic or biographical information was collected along with a self-report to all students using the Gadzella's student life stress inventory (SLSI, 1991).

The present research was designed to address the above questions. The study first sought to establish that international students experience stress; this hypothesis was supported. The secondary hypothesis, predicted international students are more prone to higher levels of stress than American students, was not supported. On the contrary, the American students experienced higher levels of stress than the international students. Overall, the existing literature presents contradictory results, pointing to the need for further research.

\section{Methods}

\subsection{Participants}

This study was conducted at a midwestern university in the U.S. using quota sampling method. Data was collected from both American and international students who volunteered to participate in the study. The international students were from India and China. Also, a hand full of students from other countries participated in the study. The total number of participants were 131 international students and 94 American students that consisted of both the graduate and undergraduate students.

\subsection{Procedure}

The criteria for inclusion of the participants in the sample for international and American students were as follows: being 18 years of age or older, and for American students, being both American-born and living in the United States. The sample included both undergraduate $(n=148)$ and graduate students $(n=73)$, and both women $(n=131)$ and men $(n=90)$. The participants were selected for the study by seeking the permission of the University authorities, departmental heads, and faculty members. The principal investigator explained the study and obtained the consent from the participants before eliciting the data. Data was collected in person from 131 American and 90 international students. Later, the data was entered into SPSS format for data analysis.

\subsection{Gadzella's Student Life Stress Inventory (1991)}

The Student Life Stress Inventory ([SLSI]; Gadzella, 1991) is a 5-point scale consisting of 51 items measuring student life stress and reactions to stress. Based on Mori's (2000) conceptual model of student stress, the SLSI measures five dimensions of stress: frustrations (delays, daily hassles, failures, lack of resources); pressures (deadlines, overload, and interpersonal relationships); conflicts (having a hard time deciding between several alternatives, desirable and 
undesirable); changes (unpleasant; too many); and self-imposed goals in daily life (imposing unattainable goals; competitiveness; worrying; procrastination). In addition, the scale also measures reactions to stress, including those which are physiological (physiological nervousness, sweating, stuttering, being exhausted, headaches); emotional (being afraid, anxious, angry, guilty, depressed); behavioral (crying, abusing self and/ or others, smoking, attempting suicide, separating oneself from others); and cognitive (analyzing stressful situations and strategies to cope with stress). These dimensions of reactions seem especially useful for understanding students' adaptation to stressful situations.

SLSI scores can range from 51 to 215 , with higher scores indicating students experienced more stressful events and reacted to them more strongly. Test-retest reliability and Cronbach's alpha's internal consistency correlations were statistically significant $(\mathrm{p}<0.05)$, with coefficients for types of stressors and reactions to stressors ranging from 0.52 to 0.85 respectively (Gadzella, 1991).

\section{Results}

\subsection{Demographics of American and International Students}

Table 1. Demographic characteristics of American and international student participants

\begin{tabular}{lccc}
\hline $\begin{array}{l}\text { Demographic } \\
\text { variable }\end{array}$ & Group & $\begin{array}{c}\text { American } \\
\text { students } \\
(\mathbf{N = 1 3 1})\end{array}$ & $\begin{array}{c}\text { International } \\
\text { students } \\
\text { (N=90) }\end{array}$ \\
\hline Nationality & American=131 & $\begin{array}{c}\text { Indian }=64 \\
\text { Chinese=10 } \\
\text { Other=16 }\end{array}$ \\
\hline Gender & Male & $31(23.66 \%)$ & $59(65.55 \%)$ \\
& Female & $100(76.33)$ & $31(34.44 \%)$ \\
\hline Age & $18-35$ & $116(88.5 \%)$ & $86(95.6 \%)$ \\
& $>35$ & $15(11.5 \%)$ & $4(4.4 \%)$ \\
\hline Student status & Undergraduate & $128(97.7 \%)$ & $20(22.2 \%)$ \\
& Graduate & $3(2.3 \%)$ & $70(77.8 \%)$ \\
\hline Current & & & \\
Academic & & & $33(36.66 \%)$ \\
Performance & Excellent & $23(25.56 \%)$ & $43(47.78 \%)$ \\
& Good & $75(83.33 \%)$ & $11(12.22 \%)$ \\
& Average & $30(33.33 \%)$ & $3(3.33 \%)$ \\
\hline
\end{tabular}

Demographic data and family support information for American and international students are presented in Table 1.

Table 1 presents students demographic details such as age, gender, students' status and current academic performance of both American and international students. These demographics were collected from all the participants and the participants remained anonymous. These demographics were collected to understand if the demographic factors impacted and were correlated to student's stress. Most of the international students were from India, with the remainder from China, Bangladesh, Pakistan, and Japan. Most students were in the 18-35 years age group. A significantly higher percentage of American students (97.7\%) were undergraduate students and (2.3\%) were graduate students.

Information on current academic performance was gathered to understand how American and international students performed in their academics. American students scored 25. 556\% and the international students scored 36. 66\% under excellent category, followed by the Good $83.33 \%$ and $47.78 \%$, Average $33.33 \%$ and $12.22 \%$, Fair 3. 33\% and 3. 33\% scores. Overall, a significant number of American students did well on their current academic performance.

\subsection{American vs. International Students' Experience of Stress}

Table 2. Levels of stress for American and international students as per the demographics

\begin{tabular}{|c|c|c|c|c|c|c|c|c|c|c|}
\hline \multirow{3}{*}{ Variable } & \multicolumn{10}{|c|}{ Student Life Stress Inventory Severity Scores } \\
\hline & \multicolumn{5}{|c|}{ American Students } & \multicolumn{5}{|c|}{ International Students } \\
\hline & $\begin{array}{c}\text { Less } \\
\text { than } \\
\text { Mild } \\
(51-89) \\
\end{array}$ & $\begin{array}{c}\text { Mild } \\
(90-121)\end{array}$ & $\begin{array}{l}\text { Moderate } \\
(122-158)\end{array}$ & $\begin{array}{c}\text { Severe } \\
(159-213)\end{array}$ & Sum & $\begin{array}{l}\text { Less } \\
\text { than } \\
\text { Mild } \\
(51-89)\end{array}$ & $\begin{array}{c}\text { Mild } \\
(90-121)\end{array}$ & $\begin{array}{l}\text { Moderate } \\
(122-158)\end{array}$ & $\begin{array}{c}\text { Severe } \\
(159-213)\end{array}$ & Sum \\
\hline \multicolumn{11}{|l|}{ Gender } \\
\hline Male & $\begin{array}{c}1 \\
(3.2 \%)\end{array}$ & $\begin{array}{c}19 \\
(61.2 \%)\end{array}$ & $\begin{array}{c}11 \\
(35.4 \%)\end{array}$ & $\begin{array}{c}0 \\
(0 \%)\end{array}$ & 31 & $\begin{array}{c}7 \\
(11.8 \%)\end{array}$ & $\begin{array}{c}29 \\
(49.1 \%)\end{array}$ & $\begin{array}{c}22 \\
(37.2 \%)\end{array}$ & $\begin{array}{c}1 \\
(1.6 \%)\end{array}$ & 59 \\
\hline Female & $\begin{array}{c}6 \\
(6 \%)\end{array}$ & $\begin{array}{c}27 \\
(27 \%)\end{array}$ & $\begin{array}{c}50 \\
(50 \%)\end{array}$ & $\begin{array}{c}17 \\
(17 \%)\end{array}$ & 100 & $\begin{array}{c}4 \\
(12.9 \%)\end{array}$ & $\begin{array}{c}8 \\
(25.8 \%)\end{array}$ & $\begin{array}{c}16 \\
(51.6 \%)\end{array}$ & $\begin{array}{c}3 \\
(9.6 \%)\end{array}$ & 31 \\
\hline
\end{tabular}




\begin{tabular}{|c|c|c|c|c|c|c|c|c|c|c|}
\hline$\frac{\text { Age }}{18-35}$ & $\begin{array}{c}7 \\
(6.44 \%)\end{array}$ & $\begin{array}{c}44 \\
(36.6 \%)\end{array}$ & $\begin{array}{c}48 \\
(42.26 \%)\end{array}$ & $\begin{array}{c}17 \\
(13.9 \%)\end{array}$ & 116 & $\begin{array}{c}10 \\
(11.6 \%)\end{array}$ & $\begin{array}{c}37 \\
(43.02 \%)\end{array}$ & $35(40.6 \%)$ & $\begin{array}{c}4 \\
(4.6 \%)\end{array}$ & 86 \\
\hline $35-49$ & 0 & 0 & $\begin{array}{c}6 \\
(100 \%)\end{array}$ & 0 & 6 & $\begin{array}{c}1 \\
(25 \%)\end{array}$ & 0 & $\begin{array}{c}3 \\
(75 \%)\end{array}$ & 0 & 4 \\
\hline $50-65$ & 0 & $\begin{array}{c}2 \\
(22.22 \%) \\
\end{array}$ & $\begin{array}{c}7 \\
(77.8 \%) \\
\end{array}$ & 0 & 9 & 0 & 0 & 0 & 0 & 0 \\
\hline \multicolumn{11}{|c|}{ Education Level } \\
\hline Senior & $\begin{array}{c}1 \\
(3 \%) \\
\end{array}$ & $\begin{array}{c}11 \\
(33.3 \%) \\
\end{array}$ & $\begin{array}{c}16 \\
(48.5 \%) \\
\end{array}$ & $\begin{array}{c}5 \\
(15.2 \%) \\
\end{array}$ & 33 & 0 & $\begin{array}{c}4 \\
(44.4 \%) \\
\end{array}$ & $\begin{array}{c}4 \\
(44.4 \%) \\
\end{array}$ & $1(11.2 \%)$ & 9 \\
\hline Junior & $\begin{array}{c}4 \\
(8 \%)\end{array}$ & $\begin{array}{c}18 \\
(36 \%)\end{array}$ & $\begin{array}{c}21 \\
(42 \%)\end{array}$ & $\begin{array}{c}7 \\
(14 \%)\end{array}$ & 50 & $\begin{array}{c}2 \\
(40 \%)\end{array}$ & $\begin{array}{c}2 \\
(40 \%)\end{array}$ & $\begin{array}{c}1 \\
(20 \%)\end{array}$ & 0 & 5 \\
\hline Soph. & 0 & $\begin{array}{c}11 \\
(40.7 \%) \\
\end{array}$ & $\begin{array}{c}13 \\
(48.1 \%) \\
\end{array}$ & $\begin{array}{c}3 \\
(11.1 \%) \\
\end{array}$ & 27 & 0 & 0 & $\begin{array}{c}4 \\
(100 \%)\end{array}$ & 0 & 4 \\
\hline Freshman & $\begin{array}{c}2 \\
(11.1 \%) \\
\end{array}$ & $\begin{array}{c}4 \\
(22.2 \%) \\
\end{array}$ & $\begin{array}{c}10 \\
(55.6 \%) \\
\end{array}$ & $\begin{array}{c}2 \\
(11.1 \%) \\
\end{array}$ & 18 & 0 & $\begin{array}{c}1 \\
(50 \%) \\
\end{array}$ & $\begin{array}{c}1 \\
(50 \%) \\
\end{array}$ & 0 & 2 \\
\hline Graduate & 0 & $\begin{array}{c}2 \\
(66.7 \%) \\
\end{array}$ & $\begin{array}{c}1 \\
(33.3 \%) \\
\end{array}$ & 0 & 3 & $\begin{array}{c}8 \\
(11.4 \%) \\
\end{array}$ & $\begin{array}{c}32 \\
(45.7 \%) \\
\end{array}$ & $\begin{array}{c}27 \\
(38.6 \%) \\
\end{array}$ & $\begin{array}{c}3 \\
(4.3 \%) \\
\end{array}$ & 70 \\
\hline \multicolumn{11}{|c|}{ Socio-economic Status } \\
\hline $\begin{array}{l}\text { Upper } \\
\text { Class }\end{array}$ & 0 & $\begin{array}{c}3 \\
(37.5 \%)\end{array}$ & $\begin{array}{c}3 \\
(37.5 \%)\end{array}$ & $\begin{array}{c}2 \\
(25.0 \%)\end{array}$ & 8 & $\begin{array}{c}1 \\
(9.1 \%)\end{array}$ & $\begin{array}{c}5 \\
(45.5 \%) \\
\end{array}$ & $\begin{array}{c}4 \\
(36.4 \%)\end{array}$ & $\begin{array}{c}1 \\
(9.1 \%)\end{array}$ & 11 \\
\hline $\begin{array}{l}\text { Middle } \\
\text { Class }\end{array}$ & $\begin{array}{c}7 \\
(6.3 \%)\end{array}$ & $\begin{array}{c}39 \\
(35.1 \%)\end{array}$ & $\begin{array}{c}52 \\
(46.8 \%)\end{array}$ & $\begin{array}{c}13 \\
(11.7 \%)\end{array}$ & 111 & $\begin{array}{c}9 \\
(12.5 \%)\end{array}$ & $\begin{array}{c}31 \\
(43.1 \%)\end{array}$ & $\begin{array}{c}31 \\
(43.1 \%)\end{array}$ & $\begin{array}{c}1 \\
(1.4 \%)\end{array}$ & 72 \\
\hline $\begin{array}{l}\text { Lower } \\
\text { Class }\end{array}$ & 0 & $\begin{array}{c}4 \\
(33.3 \%)\end{array}$ & $\begin{array}{c}6 \\
(50 \%)\end{array}$ & $\begin{array}{c}2 \\
(16.7)\end{array}$ & 12 & 0 & $\begin{array}{c}3 \\
(42.9 \%)\end{array}$ & $\begin{array}{c}2 \\
(28.6 \%)\end{array}$ & $2(28.6 \%)$ & 7 \\
\hline $\begin{array}{c}\text { Not } \\
\text { Available }\end{array}$ & $\begin{array}{c}4 \\
(5.9 \%)\end{array}$ & $\begin{array}{c}25 \\
(36.8 \%)\end{array}$ & $\begin{array}{c}28 \\
(41.25 \%)\end{array}$ & $\begin{array}{c}11 \\
(16.2 \%)\end{array}$ & 68 & $\begin{array}{c}6 \\
(8.8 \%) \\
\end{array}$ & $\begin{array}{c}29 \\
(42.6 \%) \\
\end{array}$ & $\begin{array}{c}29 \\
(42.6 \%) \\
\end{array}$ & $\begin{array}{c}4 \\
(5.9 \%) \\
\end{array}$ & 68 \\
\hline
\end{tabular}

Table 2 compares the levels of stress experienced by American and international students about gender, age, level of education and socioeconomic status. "Excellent, good, average, and fair" are categories based on the classifications used by the author who designed the instrument.

Higher scores for American students can be attributed to age, as a higher percentage (11.5\%) of the American students belonged to non-traditional and middle-aged age groups. Members of this group performed multiple roles which placed heavy demand on their time, thus constituting potential sources of stress. A lower percentage $(4.4 \%)$ of middle-aged international students attended school compared to American students. Students in senior and junior classes experienced higher stress across both groups, although this was not a statistically significant difference.

\subsection{Gender and Stress}

Gender differences between American and international students were statistically significant. Gender emerged as a key predictor of stress among students. Women students in both groups reported to have experienced stress. Nearly $25 \%$ of all women students experienced severe-stress or greater levels of stress, with a higher proportion of American women students experienced severe stress compared to women in international student group.

\subsection{Socioeconomic Status, Types of Financial Support, Family Support and Period of Stay Away from Home}

Table 3. Socioeconomic Status, Types of Financial Support, Family Support Availability and Period of Stay Away from Home

\begin{tabular}{|c|c|c|c|}
\hline Variable & American Students & International Students & Chi Square Analysis \\
\hline \multicolumn{4}{|l|}{ Socioeconomic status } \\
\hline Upper class & $12(9.16 \%)$ & $7(7.77 \%)$ & \multirow{3}{*}{$\begin{array}{l}\text { No statistically significant } \\
\text { differences between the groups }\end{array}$} \\
\hline Middle class & $111(84.73 \%)$ & $72(80.00 \%)$ & \\
\hline Lower class & $8(6.11 \%)$ & $11(12.22 \%)$ & \\
\hline \multicolumn{4}{|l|}{$\begin{array}{l}\text { Types of financial } \\
\text { Support }\end{array}$} \\
\hline School financial support* & $26(19.85 \%)$ & $18(20.00 \%)$ & \multirow{4}{*}{$\begin{array}{l}\text { Chi square }(13)=53.86 ; p \\
=.001\end{array}$} \\
\hline Fee Waiver & $4(3.05 \%)$ & $6(6.66 \%)$ & \\
\hline Part-time job at school & $10(7.63 \%)$ & $12(13.33 \%)$ & \\
\hline Other & $24(18.32 \%)$ & $8(8.88 \%)$ & \\
\hline \multicolumn{4}{|l|}{ Family Support } \\
\hline Available & $\begin{array}{c}63 \\
(40.09 \%)\end{array}$ & $\begin{array}{c}22 \\
(24.44 \%)\end{array}$ & \\
\hline
\end{tabular}




\begin{tabular}{lccc}
\cline { 2 - 3 } Not available & \multicolumn{1}{c}{$\begin{array}{c}68 \\
(51.91 \%)\end{array}$} & $\begin{array}{c}68 \\
(75.55 \%)\end{array}$ \\
\hline Period of Stay Away from Home & & & Chi square $(16)=56.525 ; p$ \\
\hline$<1$ year & $11(8.40 \%)$ & $12(13.33 \%)$ & $=.001$ \\
\hline 1- 2 years & $12(9.16 \%)$ & $22(24.44 \%)$ & \\
2-4 years & $44(33.58 \%)$ & $25(27.77 \%)$ & \\
5 and more & $16(12.21 \%)$ & $31(34.44 \%)$ & \\
\cline { 2 - 4 }
\end{tabular}

* School financial support was inclusive of fee waivers for two of the American students and international students.

Gender emerged as an important predictor of stress. $34.44 \%$ of international students and $76.33 \%$ of American students included in the present study reported to have higher levels of stress, this included women students from both the groups.

No significant differences were found between the socioeconomic background of American and international students as 80 percent of the respondents from both the groups belonged to the middle class as per the students' self-reports, around $9.16 \%$ of American students were from a lower socioeconomic class background, while $84.73 \%$ and $6.11 \%$ were of the middle or upper class, respectively. Among international students, around $7.77 \%$ belonged to a lower-class socioeconomic status while $80.00 \%$ and $12.22 \%$ of the students belonged to the middle or upper socioeconomic status. A slightly higher proportion of American students were from the lower socioeconomic status and experienced moderate to severe levels of stress compared to the other two groups.

A higher percentage of international students approximating $40 \%$ received university fellowships, scholarships, and fee waivers. Many international students had part time jobs in the university due to their status as graduate students compared to $20 \%$ of American students. American students were mainly undergraduates who were dependent on other jobs.

Availability of family support for both international and American students showed significant differences. Family and social support was not much available for most of the international students. $40 \%$ of American students and $25 \%$ of international students received family support, as assessed by the question "do you have family members (immediate or extended) in the vicinity of school?"

On a related note, the period of stay away from home for most of the international students was less than two years. However, most American students had also moved away from their hometowns to attend college, possibly affecting their stress and comfort levels as well. Students' educational status and study was a major contributory factor towards high stress levels. 77\% of the American students were sophomores and juniors in the undergraduate program pursuing studies in social sciences and $70 \%$ of the international students were in the graduate program pursuing studies in engineering, computer science, and business disciplines. As students advanced in their studies, they reported more expectations and academic demands, presenting potential sources of stress in the junior and senior years, while contributing to their academic performance. College education can be highly stressful for those in the transition phase from high school to college.

American students who had less support stated they experienced moderate to severe levels of stress.

\subsection{Stressors and Reactions to Stressful Events}

Table 4. Comparison scores of American and international students by stress subscale

\begin{tabular}{|c|c|c|c|c|c|}
\hline Stress dimension & Students & Mean & $\begin{array}{l}\text { Standard } \\
\text { deviation }\end{array}$ & $\begin{array}{r}t=\text { value. } \\
\mathrm{df}=219\end{array}$ & $\begin{array}{c}\begin{array}{c}\text { Significance } \\
\text { Level }\end{array} \\
\end{array}$ \\
\hline \multicolumn{6}{|l|}{ I. Stressors } \\
\hline \multirow{2}{*}{ a. Frustrations } & American & 16.75 & 4.03 & \multirow[t]{2}{*}{$\mathrm{t}=1.48$} & \multirow{2}{*}{0.05} \\
\hline & International & 15.90 & 4.44 & & \\
\hline \multirow{2}{*}{ b. Pressures } & American & 15.14 & 3.89 & \multirow{2}{*}{$\mathrm{t}=2.75$} & \multirow{2}{*}{0.05} \\
\hline & International & 13.63 & 4.16 & & \\
\hline \multirow{2}{*}{ c. Conflicts } & American & 6.72 & 2.09 & \multirow{2}{*}{$\mathrm{t}=-1.30$} & \multirow{2}{*}{0.05} \\
\hline & International & 7.11 & 2.34 & & \\
\hline \multirow{2}{*}{ d. Changes } & American & 7.11 & 2.68 & \multirow{2}{*}{$\mathrm{t}=0.525$} & \multirow{2}{*}{0.05} \\
\hline & International & 6.92 & 2.65 & & \\
\hline \multirow{2}{*}{ e. Self-imposed } & American & 20.05 & 4.24 & \multirow{2}{*}{$\mathrm{t}=-0.04$} & \multirow{2}{*}{0.05} \\
\hline & International & 20.07 & 4.59 & & \\
\hline \multicolumn{6}{|c|}{ II. Reactions to stressful events } \\
\hline \multirow{2}{*}{ a. Physical reactions } & American & 30.41 & 9.89 & \multirow{2}{*}{$\mathrm{t}=4.11$} & \multirow{2}{*}{ Significant } \\
\hline & International & 25.01 & 9.12 & & \\
\hline b. Emotional reactions & American & 11.25 & 4.09 & $t=3.64$ & Significant \\
\hline
\end{tabular}




\begin{tabular}{|c|c|c|c|c|c|}
\hline & International & 9.30 & 3.67 & & \\
\hline \multirow{2}{*}{ c. Behavioral reactions } & American & 16.90 & 5.30 & \multirow{2}{*}{$\mathrm{t}=3.89$} & \multirow{2}{*}{ Significant } \\
\hline & International & 14.12 & 5.10 & & \\
\hline \multirow{2}{*}{ d. Cognitive reactions } & American & 5.74 & 2.17 & \multirow{2}{*}{$\mathrm{t}=-0.32$} & \multirow{2}{*}{0.05} \\
\hline & International & 5.84 & 2.23 & & \\
\hline
\end{tabular}

Table 4 presents descriptive statistics and $t$-test values for the above variables. Types of stressors and reactions to stress according to Gadzella's scale (1991) were examined using Levene's test ( $t$-test) for equality of means between American and international students. American students reported significantly higher scores on stressors such as pressures (deadlines, overload, interpersonal relationships), but the groups did not differ on other types of stressors.

Significant statistical differences were evident in the stress reactions of international and American students to situations in daily life (physiological, emotional, and behavioral realm American students scored significantly higher mean scores on all three dimensions. There were no significant differences in the mean scores for cognitive reactions between international and American students.

\section{Discussion}

This study demonstrated that international students experienced stress, though statistically at lower level than the American students. These results were partially in contrast to the initial hypothesis. American students experienced higher levels of stress than international students as per the mean scores on SLSI (1991). Furthermore, women students' higher mean scores showed statistical significance compared to men's scores irrespective of American and international student status.

Significantly, gender emerged as an important demographic variable. This study clearly illustrated that more women than men in the sample experienced moderate to severe levels of stress, a finding common to both the American and international student groups. These findings are consistent with the findings of (Misra et al. 2003; Misra \& Castillo 2004).

Evidence showed that American students experienced higher stress levels, but no specific item was rated as a stressor. Furthermore, a higher percentage of American women students experienced severe levels of stress compared to the international women students.

American students indicated lower levels of available family support, this possibly contributed to their experience of moderate and severe levels of stress. Length or period of stay away from home impacted the comfort levels of both the groups and contributed to the American students' higher levels of stress.

A higher percentage of international students received financial support and fee waivers from their school/university. Larger number of international students were in graduate programs and were thus eligible for graduate assistantships and tuition waivers, as compared to undergraduate students, who had to rely on part-time jobs and scholarships. This finding is consistent with past research (Ying \& Liese, 1991).

When comparing undergraduate students to graduate students, undergraduate students in their junior and senior years experienced more stress, although this difference was not statistically significant. On one hand, first year undergraduate students were transitioning from high school to college life, which could explain undergraduate students' high levels of stress. On the other hand, students in graduate-level advanced classes may have experienced stress due to high academic demands and expectations.

Socio-economic status was a major moderating factor. A higher percentage of students from lower socioeconomic status experienced moderate and severe levels of stress. A student from higher socioeconomic status would receive financial support from the family for the student to attend school without taking huge amounts of student loans or working long hours, enabling these students to pay fees on time, take care of monthly bills, and importantly, allow time for relaxation. Both American and international student groups reflected similar distributions across the socio-economic status spectrum, making it possible to compare the two groups.

Overall, these research findings are consistent with prior research. The findings of this research reveal that international students did experience stress, though not at the level American students do, as indicated by scores on Gadzella's (SLSI, 1991). Findings are also consistent with prior research reporting higher levels of stress among college women as compared to men, and among the American students as compared to international students (Misra \& Castillo, 2004).

\section{Limitations}

This study has limitations from several perspectives. This research intended to measure stress and identify stressors as experienced by international and American students. The study could not however use a random sample, as it was not feasible to secure a complete list of students due to the university's restrictive policy. Therefore, quota sampling was used to obtain surveys from American and international students. Other limitations of the study were lack of demographic 
uniformity across the two samples, particularly with regards to the students age groups and levels of education.

Despite these limitations, this research offers some important insights about factors associated with stress, and those that moderate stress. Future researchers could conduct studies using these differences and further by controlling the demographic factors such as age, gender, and educational performance. Studies could also use random sampling, and/or ensure a representation of international students from different countries, to achieve better generalizability.

\section{Implications}

This study found that high level of stress was experienced by both international and American students, although international students experienced less stress than American students. This remains a significant question for future researchers. Research on this topic can help to replicate the findings regarding stress levels and stressors of American and international students. In addition to addressing differences of levels of stress in American vs. international students, research should be designed to explore stress among non-traditional students, and across age and racial differences among American students.

This current research revealed that college women experienced higher levels of stress than college men regardless of country of origin. Hence, studies examining more closely causes of women students' stress should be undertaken.

Most Universities could create more opportunities and encourage both American students and international students to associate with appropriate student organizations for social interaction and emotional support. They could also offer support groups exclusively for women to help in stress reduction. A survey to measure stress should be administered to all college students as a part of their general health screening, to prompt students at risk for negative stress-related effects to seek counseling or necessary medical treatment. Incorporating these components to induction and orientation sessions and academic advisory regarding the expectations of the educational program could be of great assistance to students. There should be serious and systematic efforts made to offer professional services for physical and mental health problems, particularly for American-born and women students.

Students should seek interventions to deal with stressful situations when they are in the process of college adaptation. Encouraging students to take advantage of pre-existing programs will certainly be highly beneficial.

Policies to smoothen the college adaptation process, along with academic support, and curriculum accommodations, would greatly facilitate students' journey to success. Interventions would ideally address the differential treatment meted out to different gender, students' age, status, and socioeconomic class.

\section{Conclusion}

This study concluded that the American students reported higher levels of stress than the international students. However, some members of both the international and the American students experienced moderate to severe levels of stress. Furthermore, women in both the American and the international students reported higher levels of stress than their male counterparts. The factors which showed correlation with high stress levels were age, level of education, and socioeconomic support. Counseling centers and mental health professionals should design culturally acceptable interventions to meet the student needs and teach stress management strategies to facilitate college students' adjustment and adaptation to college. Creating provisions for students to meet the demands of higher education would ease college students' adaptation to U.S. colleges and universities. This could substantially contribute to students' retention and students' success.

\section{Acknowledgements}

I express my gratitude to my Ph.D. supervisors Dr. B.C. Muthayya, Osmania University, India \& Dr. Terry, C. Tollar for supervision and data collection University of Toledo, United States.

\section{References}

Abouserie, R. (1994). Sources and levels of stress in relation to locus of control and self-esteem in university students. Educational Psychology, 14(3), 323-330. https://doi.org/10.1080/0144341940140306

Almawi, W., Tamim, H., Al-Sayed, N., Arekat, M. R., Al-Khateeb, G. M., Baqer, A., Tutanji, H., \& Kamel, C. (2008). Association of comorbid depression, anxiety, and stress disorders with Type 2 diabetes in Bahrain, a country with a very high prevalence of Type 2 diabetes. Journal of endocrinological investigation, 31(11), 1020-1024. https://doi.org/10.1007/BF03345642

Aneshensel, C. S. (1986). Marital and employment role-strain, social support, and depression among adult women. In Hobfoll, S. (Ed.), Stress, social support, and women (pp. 99-114). Washington, DC: Hemisphere.

Aneshensel, C. S. (1988). Disjunctures between public health and medical models [Paper presentation]. American Public Health Association Annual Meeting, Boston, MA, United States. 
Appley, M. H., \& Trumbull, R. (1967). On the Concept of Psychological Stress, in Psychological Stress: Issues in Research (M. H. Appley and R. Trumbull, eds), New York: Appleton-Century-Crofts.

Arnett, J. (2000). Emerging adulthood: A theory of development from the late teens through the twenties. American Psychologist, 55(5), 469-480. https://doi.org/10.1037/0003-066X.55.5.469

Atkinson, J. M. (1988). Coping with England. Thorsons Publishers Limited.

Bailey, J. M., \& Dynarski, M. S. (2011). Inequality in postsecondary education. In Greg J. Duncan \& Richard J. Murnane (eds.), Whither Opportunity. Russell Sage. pp. 117-132.

Barnett, R. C., Beiner, L., \& Baruch, G. K. (1987). Gender and Stress. New York: Free Press.

Barret, N. S. (1979). Women in the job market: Occupations, earning and career opportunities. In R.E. Smith (Ed.), The subtle revolution pp (31-62). Washington, DC: The Urban Institute.

Beena, C., \& Poduval, P. R. (1992). On gender differences in work stress of executives. Psychological Studies, 37(2 \& 3), 109-113.

Belley, P., \& Lochner, L. (2007). The changing role of family income and ability in determining educational achievement (no. w13527). National Bureau of Economic Research; Cambridge, MA. https://doi.org/10.3386/w13527

Boynton Health Services, University of Minnesota. Health and Academic Performance, Minnesota Postsecondary Students. Minneapolis, MN: University of Minnesota; 2009. [Google Scholar]

Bradely, G. (2000). Responding effectively to the mental health needs of international students. Higher Education, 39, 417-433. https://doi.org/10.1023/A:1003938714191

Cannon, W. B. (1929). Bodily changes in pain, hunger, fear and rage. D. Appleton \& Co. https://doi.org/10.1097/00007611-192909000-00037

Church, A. T. (1982). Sojourner adjustment. Psychological Bulletin, 91, 540-572. https://doi.org/10.1037/0033-2909.91.3.540

Clarke, D. E. (1995). Vulnerability to stress as a function of age, sex, locus of control, hardiness and type A personality. Social Behavior and Personality, 23, 285-286. https://doi.org/10.2224/sbp.1995.23.3.285

Cloud, R. (1991). A stress management primer for college administrators. Educational Record, 72(3), 31-34.

Ellis, A. (1989). Rationale-emotive therapy. In R. J. Corsin \& D. Wedding (Eds.), Current Psychotherapies (4th ed., pp. 197-238). Peacock.

Gadzella, B. M. (1991). Student-Life Stress Inventory [Paper presentation]. Texas Psychological Convention, San Antonio, TX, United States.

Gilbert, L. A., \& Holahan, C. K. (1982). Conflicts between student/professional, parental, and self-development roles: A comparison of high and low effective copers. Human Relations, 35, 635-648. https://doi.org/10.1177/001872678203500802

Gilbert, L. A., \& Rachlin, V. (1987). Mental health and psychological functioning of dual-career families. The Counseling Psychologist, 15, 7-49. https://doi.org/10.1177/0011000087151002

Harris, H. W. (1972). The relationship of life changes to academic performance among selected college freshman at varying levels of college readiness [Unpublished Doctoral Dissertation]. Texas State University.

Hirsch, J. K., \& Ellis, J. B. (1996). Differences in life stress and reasons for living among college suicide ideators and non-ideators. College Student Journal, 30, 377-384.

Hudd, S., Dumlao, J., Erdmann-Sager, D., Murray, D., Phan, E., Soukas, N., et al. (2000). Stress at college: Effects on health habits, health status and self-esteem. College Student Journal, 34(2), 217-227.

Kena, G., Musu-Gillette, L., Robinson, J., Wang, X., Rathbun, A., Zhang, J., ... Dunlop Velez, E. (2015). The Condition of Education 2015 (NCES 2015-144). U.S. Department of Education, National Center for Education Statistics. Washington, DC. Retrieved from http://nces.ed.gov/pubsearch.

Lazarus, R. S. (1985). Some current issues and controversies. In A. Monat \& R. S. Lazarus (Eds.), Stress and coping: An anthology. Columbia University Press.

Lazarus, R. S., \& Folkman, S. (1984). Stress appraisal and coping. Springer.

Lee, P. A., \& Ying, Y. (2001). Asian American adolescents' academic achievement: A look behind the model minority 
image. Journal of Human Behavior in the Social Environment, 3, 35-48. https://doi.org/10.1300/J137v03n03_04

Leong, F. T., Mallinckrodt, B., \& Kralj, M. M. (1990). Cross-cultural variations in stress and adjustment among Asian and Caucasian graduate students. Journal of Multicultural Counseling and Development, 18(1), 19-28. https://doi.org/10.1002/j.2161-1912.1990.tb00433.x

Lewthwaite, M. (1996). A study of international student's perspective on cross-cultural adaptation. International Journal for the Advancement of Counseling, 19, 167-185. https://doi.org/10.1007/BF00114787

McBride, A. B. (1990). Mental health effects of women's multiple roles. American Psychologist, 45, 381-384. https://doi.org/10.1037/0003-066X.45.3.381

Misra, R., \& Castillo, L. G. (2004). Academic Stress Among College Students: Comparison of American and International Students. International Journal of Stress Management, 11(2), 132-148. https://doi.org/10.1037/1072-5245.11.2.132

Misra, R., Crist, M., \& Byrant. C. J. (2003). Relationships among life stress, social support, academic stressors and reactions to stressors of international students in the United States. International Journal of Stress Management, 10(2), 137-157.

Mori, S. C. (2000). Addressing the mental health concerns of international students. Journal of Counseling \& Development, 78(2), 137-144. https://doi.org/10.1002/j.1556-6676.2000.tb02571.x

National Institute of Child Health and Human Development. stress system malfunction could lead to serious, life-threatening disease. National Institute of Child Health and Human Development; 2002. Retrieved April 5, 2009, from http://www.nichd.nih.gov/news/releases/stress.cfm [Google Scholar]

Newcomb, M. D., Huba, G. J., \& Bentler, D. M. (1981). A multidimensional assessment of stressful life events among adolescents: Derivation and correlates. Journal of Health and Social Behavior, 22, 400-415. https://doi.org/10.2307/2136681

Oberg, K. (1960). Cultural Shock: Adjustment to New Cultural Environments. Practical Anthropology, Os-7(4), 177-182. https://doi.org/10.1177/009182966000700405

Pearlin, L. I., Morton, A. L., Elizabeth, G. M., \& Joseph, T. M. (1981). "The Stress Process." Journal of Health and Social Behavior, 22, 337-56. https://doi.org/10.2307/2136676

Pierceall, E. A., \& Keim, M. C. (2007). Stress and coping strategies among community college students. Community College Journal of Research and Practice, 31(9), 703-721. https://doi.org/10.1080/10668920600866579

Rao, K., Moudud, Z., \& Subbakrishna, D. K. (2000). On appraisal of stress and coping behavior in college students. Journal of the Indian Academy of Applied Psychology, 26(1-2), 5-13.

Roisman, G. I., Masten, A. S., Coatsworth, J. D., \& Tellegran, A. (2004). Salient and emerging developmental tasks in the transition to adulthood. Child Development, 75, 123-133. https://doi.org/10.1111/j.1467-8624.2004.00658.x

Selye, H. (1956). The stress of life. McGraw-Hill.

Sherman, A. G., \& Walls, J. W. (1995). Gender differences in the relationship of moderator variables to stress and symptoms. Psychology and Health, 10, 321-331. https://doi.org/10.1080/08870449508400246

Siegel, J. M., \& Brown, J. D. (1988). A prospective study of stressful circumstances, illness symptoms, and depressed mood among adolescents. Developmental Psychology, 24, 715-721. https://doi.org/10.1037/0012-1649.24.5.715

Sue, S., \& Okazaki, S. (1990). Asian American educational achievements: A phenomenon in search of an explanation. American Psychologist, 45, 913-920. https://doi.org/10.1037/0003-066X.45.8.913

Tolan, P., Miller, L., \& Thomas, P. (1988). Perceptions and experiences of types of social stress and self-image among adolescents. Journal of Youth and Adolescence, 17, 147-163. https://doi.org/10.1007/BF01537964

Vanfossen, B. E. (1981). Sex differences in the mental health effects of spouse support \& equity. Journal of Health \& Social Behavior, 22, 130-143. https://doi.org/10.2307/2136289

Vroegap, P. (1975). Stress and anxiety in modern life: A fantasy. In C.D. Spielberger \& I.G. Sarason (Eds.), Stress and Anxiety (Vol.1, pp. 312-314). Hemisphere.

Wan, T. Y., Chapman, D. W., \& Biggs, D. A. (1992). Academic stress of international students attending U.S. universities. Research in Higher Education, 33(5), 607-623. https://doi.org/10.1007/BF00973761

Wei, M., Heppner, P. P., Mallen, M. J., Ku, T. Y., Liao, K. Y. H., \& Wu, T. F. (2007). Acculturative stress, perfectionism, years in the United States, and depression among Chinese international students. Journal of Counseling Psychology, 
54(4), 385-394. https://doi.org/10.1037/0022-0167.54.4.385

Ying, Y. W., Lee, P. A. \& Tsai, J. L. (2004). Inventory of college challenges for ethnic minority students: Psychometric properties of a new instrument in Chinese Americans. Cultural Diversity and Ethnic Minority Psychology, 10(4), 351-364. https://doi.org/10.1037/1099-9809.10.4.351

Ying, Y., \& Liese, L. H. (1991). Emotional well-being of Taiwan students in the U.S.: An examination of pre-to post-arrival differential. International Journal of Intercultural Relations, 15, 345-366. https://doi.org/10.1016/0147-1767(91)90007-4

Yogev, S. (1981). Do professional women have egalitarian marital relationships? Journal of Marriage and the Family, 43, 865-871. https://doi.org/10.2307/351343

Yoon, E., \& Portman, T. A. A. (2004), Critical Issues of Literature on Counseling International Students. Journal of Multicultural Counseling and Development, 32, 33-44. https://doi.org/10.1002/j.2161-1912.2004.tb00359.x

Zwingmann, C. A., \& Gunn, A. G. (1983). Uprooting and health: Psychosocial problems of students from abroad. Division of Mental health, World Health Organization.

\section{Copyrights}

Copyright for this article is retained by the author(s), with first publication rights granted to the journal.

This is an open-access article distributed under the terms and conditions of the Creative Commons Attribution license which permits unrestricted use, distribution, and reproduction in any medium, provided the original work is properly cited. 